Madrygal. Revista de Estudios Gallegos

ISSN: 1138-9664

\title{
Unhas cantas palabras sobre un relato que rende tributo á Palabra, ás palabras ${ }^{1}$
}

Xesús Alonso Montero

O libro que hoxe nos convoca aquí titúlase Icía quere cambiar o mundo, libro que, segundo a cuberta e maila portada, ten como autora a Fina Casalderrey, á gran narradora Fina Casalderrey. Se os tratados non se trabucan, Fina $\mathrm{Ca}-$ salderrey naceu no ano 1952, o que a converte, nesta altura, nunha escritora adulta, xa lonxe da idade de Icía, a nena que é a protagonista e a inspiradora do relato que hoxe nos convoca: protagonista, musa e, moi probablemente autora deste gran relato, un relato, miñas donas e meus señores, que non é alleo á man da señora Casalderrey.

Protagonizan o libro, con Icía, o seu irmán Fiz, o seu avó Félix, dous mestres (Ramón e Ágata), a señora Rosa e varios compañeiros seus na aula (Xandra, Xocas, Baia, Cristovo, Fuco). No libro, Icía, Fiz e os seus colegas, levados por Ágata e Ramón, os mestres, visitan o Parlamento de Galicia, e axiña Icía se decata de que o Parlamento non é unha institución máis do país, de que é algo así como o templo da Palabra, o santuario das palabras. Icía, que vén da terra de Penaval, agora ofendida na súa flora e na súa fauna, non tarda en descubrir que, no Parlamento, onde só se fala, pódese cambiar o mundo, cando menos un pouco. Porque ela, antes de visitaren o Parlamento, xa estaba convencida de que as palabras moven, conmoven, promoven...

E foi naquel intre cando viviu, dentro do Parlamento, un conxunto de peripecias nas que o episodio máis salientable protagonizárono aves do país de nomes moi eufónicos: lavercas, xílgaros, liñaceiras, merlos, paporrubios... O lector, páxinas adiante, sae da súa perplexidade: o estraño episodio no edificio do Parlamento fora un soño, pero un soño no que esta fauna canora falaba como falan as persoas, e, como as persoas conscientes dos seus dereitos, "reivindicaban teren un territorio de seu". Fosen soberanistas ou non, estas aves reivindicaban, no soño de Icía, algo: algo formulado por seres que eran poesía pura. Decontado, a reivindicación provocou, por parte de non sabemos qué forzas, disparos, disparos eficaces, tanto que houbo bandadas que voaron cheas de pánico e outras caeron "fulminadas naquela alfombra da cor do sangue". Xa aquí, señoras e señores, se estivese entre nós a autora do maxistral relato, preguntaríalle se esta escena, protagonizada por aves atemorizadas no Parlamento de Galicia, é ou non un trasunto do $23 \mathrm{~F}$, do tristemente célebre asalto ó Parlamento de España.

Foi un pesadelo, un soño de Icía, que ten como escenario os salóns e os corredores do Parlamento de Galicia. Xa esperta, Icía segue a recoñecer que o Parlamento era o lugar da Palabra, non o da violencia, nin sequera o dos gritos e outras cacofonías. Para a nosa Icía, xa fóra do enigmático soño, había, na Cámara do Hórreo, tres palabras case máxicas: Iniciativa Lexislativa Popular. Só esa maxia podía salvar da barbarie antiecoloxista, no Alto da Moa, en Penaval, a vida da máis famosa e briosa fauna avícola do mundo. Icía e o seu irmán Fiz, que tamén eran pícaros de acción, idearon unha curiosa e sofisticada estrataxema para conseguir o que parecía imposible: xuntar dez mil firmas para que o Parlamento admitise, coas súas consecuencias, a Iniciativa Lexislativa Popular ideada para salvar en Penaval un fragmento moi valioso da

1 Presentación no Parlamento de Galicia, o 19 de xuño de 2015. 
riqueza zoolóxica, estética e canora do mundo. Ese día, no Parlamento, lonxe de seren abatidos, cantaron os estorniños, os xílgaros, as lavandeiras, os merlos e outros músicos do secular Orfeóns das fragas e dos soutos de Penaval.

Xa no último capítulo do libro, Icía comunícalle ó seu avó o que quere ser de maior: quere cambiar o mundo coa arma das palabras. Por conseguinte, Icía, de maior, quere ser parlamentaria, pero parlamentaria ó servizo de determinadas palabras: amizade, esperanza, felicidade, paz, igualdade, harmonía, ledicia, solidariedade, xustiza, irmandade, tenrura, prosperidade...

Tales palabras, tales substantivos, tales voces -construídas cunha fonética ética ateigada de nobreza- protagonizan, aínda que non se pronuncien en certos capítulos, este libro. Tamén o protagonizan. Son as palabras que máis moven, conmoven e promoven o corazón infantil de Icía, nome -teñámolo moi en contada padroeira da música no noso santoral (Icía é Cecilia, Santa Cecilia).

A autora do libro, sexa ou non Fina Casalderrey, identificouse co espírito fraterno, sensible e xeneroso de Icía, e tamén coa súa condición musical, razón pola cal no seu programa político non está ausente a palabra harmonía. A autora deste relato identificouse totalmente con Icía, coa nena Icía, ou sexa, cun ser humano que fala desde a música da inocencia e que aínda cre que nas promesas dos maiores non hai reviravoltas. Por iso a autora, adulta, escribe desde a Icía nena que aínda leva dentro, desde a Icía que non quere perder. Escribindo desde ese manancial puro, desde ese humus case arcádico, Fina Casalderrey, transcritora perfecta, conta as peripecias -as vividas e as soñadas- duns nenos e nenas de Galicia que visitan, como actividade extraescolar, o Parlamento do seu país. Xa no templo das palabras, Icía, que porta a arpa dos sentimentos, chega ó convencemento de que as palabras, nomeadamente en santuarios como o do Hórreo, poden cambiar o mundo, cando menos un pouquiño.

Para algúns, o libro que hoxe nos convoca ten como autor un nome aínda non rexistrado pola erudición literaria: Icía Casalderrey. Por se fose pouco, o volume que nos cita aquí contén un prólogo, tan breve como atinado, de Pilar Rojo, Presidenta do Parlamento, e unhas ilustracións moi axeitadas de Carmen Pernas. Cómpre tamén agradecer a intervención do editor ou do impresor do libro, que estampou na súa capa unha escolma das palabras coas que Icía pensaba cambiar o mundo (irmandade, esperanza, paz, etc.).

Xa postos a esclarecermos a cuestión da autoría do extraordinario relato, de Icía é o universo de bondade, de inocencia, de entusiasmo e de limpeza, e de Casaderrey, engaiolada por tódalas Icías de Galicia, é a literatura, a fluencia da prosa, a lingua ben labrada, as intrigantes escenas de ficción e a experta man da narradora.

Hai tempo que os lectores e a crítica, dentro e fóra de Galicia, consagraron a narrativa de Fina Casalderrey; hoxe, 19 de xuño de 2015, nace, consagrándose xa, unha nova escritora. Chámase, en realidade, Icía Casalderrey. Todos estamos de noraboa! 